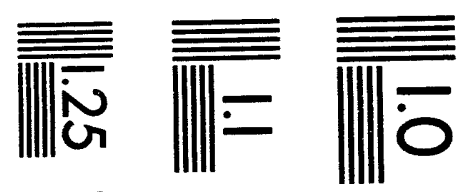

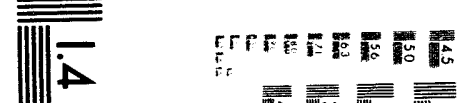

$$
\begin{aligned}
& \overline{\underline{\underline{\underline{W}}}} \overline{\underline{\underline{\underline{n}}}}
\end{aligned}
$$

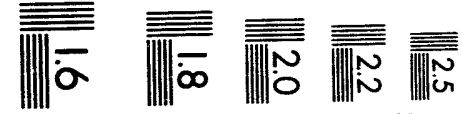



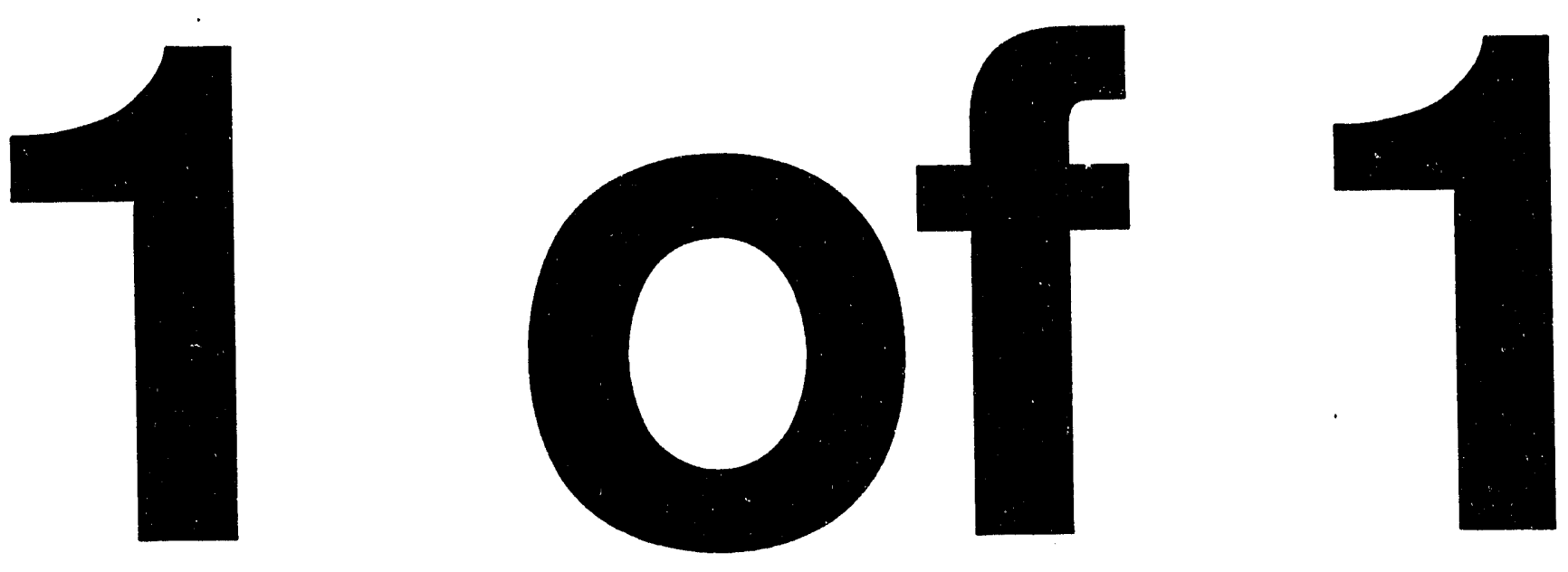


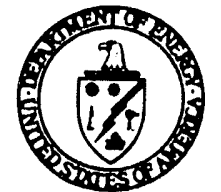

\section{Loss of Interim Status (LOIS) Under RCRA}

BACKGROUND:

The Resource Conservation and Recovery Act (RCRA) requires owners and operators of facilities that treat, store, or dispose of hazardous waste (TSDFs) to obtain an operating permit. Recognizing that it would take EPA many years to issus operating permits to all RCRA facilities, Congress created "interim status" under Section 3005 (e) of the Act. Interim status allows facilities to operate under Subtitle C of RCRA until their parmits are issued or denied. This information brief dofines interim stalus and describes how hilure to meat interim status requirements may lead to loss of interim status (LOIS).

STATUTE: Resource Conservation and Recovery Act (RCRA).

REGULA TION: $\quad 40$ CFR Pert 270, Subpart G (interim Status).

REFERENCES: 1. State Authorization to Regulate the Hazardous Components of Radianctive Mixed Waste Under RCRA, 51 FR 24504, July 3, 1986;

2. Clarification of Interim Status Quallication Requirements for the Hazardous Components of Radioactive Mixed Waste, 53 FR 37045, September 23, 1988;

3. Memorandum on Hammer Dates for Mixed Waste Storage and Treatment Units from the Director, Permits and State Programs Division, Otfice of Solid Waste, EPA, to thw Chief, Wasto Management Branch, Region X, EPA, March 21, 1888;

4. Memorandum on Clarification of RCRA Issues Pertinent to the Waste leolation Pilot Plant from the Director, Office of Solid Waste, EPA, to the Director, Office of Environmental Guidance and Compliance, DOE, August 25, 1988;

5. Letter Requesting EPA's Confirmation of the Ellgibility of the WIPP for Interim Status from the Assistant Secretary, Environment, Safoty and Health, DOE, and the Assistant Secretary, Environmentel Restoration and Waste Management, DOE, to the Assistant Administrator for Solid Wasto and Emnrgency Response, EPA, March 6, 1992;

6. Letter Clarifying EPA's Position Regarding the Status of the WIPP and Other Facilities in the DOE Complex trom the Assistant Administrator for Solid Waste and Emergency Response, EPA, to the Assistant Secretary, Environment, Safety and Health, DOE, April 27, 1992.

\section{What is interim status?}

Interim status is the period during which the owner/operator of a ISDF is treated as having been issued a RCRA permit even though a final determination on the permit has not yet been made by the regulator. Owners/operators of TSDFs in existence on November 19,1980, or brought under Subtitle C regulation due to a legislative or regulatory change, may continue to operate as if they have a permit until their permit is issued or denied as long as they:

- submit notification of hazardous waste activity and describe the location and general nature of the activity under section 3010(a) of RCRA [40 CFR 270.70],

a submit a RCRA Part A permit application six months after the publication of regulations that render the facility subject to 40 CFR 265 standards, or 30 days after the facility first becomes subject to these standards [40 CFR 270.10],

a comply with applicable 40 CFR 265 standards, and

D submit a RCRA Part B permit application within 6 months of a request for such application by an EPA Regional Administrator or the director of the State environmental agency administering the $R$.RA program [40 CFR 270.10].

Owners/operators of land disposal facilities must submit a RCRA Part B permit application, groundwater monitoring certification, and financial responsibility certification within 12 months of becoming subject to 40 CFR 265 standards. (Federal facilities are exempt from financial responsibility requirements). Failure to meet any of the above requirements can result in LOIS.

If EPA or an authorized State decides to grant a permit to a TSDF, the facility becomes subject to the requirements specified in its permit and the $40 C F R 264$ standards applicable to the facility.
If a permit is denied, the facility owner/operator will be notified that interim status is terminated. The facility owner/operator must submit a closure plan to the applicable regulatory authority within 15 days of termination of interim status [40 CFR 265.112 (d)(3)(i)]. Closure must be accomplished within 90 days of closure plan approval unless a longer time period is approved by the applicable regulatory authority [40 CFR 265.113(a)].

\section{Are new facilities eligible for Interim status?}

"New" facilities (i.e., facilities not in existence or under construction on the effective date of the statutory or regulatory requirements rendering them subject to RCRA permit regulations) are not eligible for interim status. Owners and operators of new facilities are required to submit complete RCRA permit applications (Parts $A$ and $B$ ) at least 180 days before construction of the facility is expected to begin.

How did the promulgation of the 1984 Hazardous and Solid Waste Amendments (HSWA) to RCRA alter permit application requirements?

HSWA set deadlines ('hammers") for facilities with interim status as of November 8, 1984, to submit RCRA Part B permit applications. Failure to meet these deadlines, listed below, results in LOIS.

- Owners/operators of land disposal units were required to submit their RCRA Part B permit applications by Novembet 8,1985 , to prevent LOIS on that date.

D Owners/operators of incinerators were required to submit their RCRA Pan B permit applications. by November 8, 1986, to prevent LOIS on November; $8 ; 1089$. 


\section{DISCLAIMER}

This report was prepared as an account of work sponsored by an agency of the United States Government. Neither the United States Government nor any agency thereof, nor any of their employees, makes any warranty, express or implied, or assumes any legal liability or responsibility for the accuracy, completeness, or usefulness of any information, apparatus, product, or process disclosed, or represents that its use would not infringe privately owned rights. Reference herein to any specific commercial product, process, or service by trade name, trademark, manufacturer, or otherwise does not necessarily constitute or imply its endorsement, recommendation, or favoring by the United States Government or any agency thereof. The views and opinions of authors expressed herein do not necessarily state or reflect those of the United States Government or any agency thereof. 
- Owners/operators of treatment or storage units were required to submit their RCRA Pan B permit applications by November 8, 1988, to prevent LOIS on November 8, 1992.

Is the November 8, 1992, LOIS date applicable to radioactive mixed waste (RMW) treatment and storage units at DOE facilities?

The November 8,1992 , LOIS date is applicable to storage or treatment facility units that obtained or should have obtained interim status by November 8,1984 and failed to submit their RCRA Part B permit applications by November 8, 1988. Prior to EPA's publication of a July 3,1986, Federal Register notice stating that RMW was regulated under RCRA, there was confusion on the applicability of RCRA requirements to RMW. A Federal Register notice published by EPA on September 23, 1988, specifically addressed the permit application deadlines that would have to be met by RMW management units to retain interim status. These Federal Register notices and EPA policy memoranda (March 21, 1988; August 25, 1988) directly addressing the applicability of the HSWA hammer dates to RMW assumed that the HSWA hammers were not applicable to RMW streams.

In a 1991 ruling, the U.S. District Court for the District of Columbia stated that EPA's July 3, 1986, notice did not constitute a regulatory change and that RMW had been subject to regulation under Subtitle C of RCRA since November 19,1980 [783 F. Supp. 628 (D.D.C. 1991)]. The District Court's ruling contradicted the guidance on interim status qualification requirements applicable to RMW that EPA provided in its September 23, 1988, Federal Register notice.

DOE appealed the District Court's ruling and asked EPA to reconfirm their previous guidance in a March 6, 1992, letter. In an April 27, 1992, response, EPA confirmod that in EPA's view, the 1986 Federal Register notice constituted a regulatory change in that EPA was not regulating RMW prior to this time. On July 10, 1992, the U.S. Court of Appeals for the District of Columbia reversed the District Court's ruling. Concluding that RCRA itself was ambiguous conceming its applicability to RMW, the appeals court said it would defer to EPA's interpretation (1992 U.S. App. LEXIS 15502).

\section{What permit application deadlines must be met by DOE's RMW management units to prevent LOIS?}

According to the September 23, 1988, Federal Register notice mentioned above, the following deadlines apply to DOE's RMW management units in existence or under construction by July 3, 1986. (RMW management units that were not in existence or under construction as of July 3,1986 , are considered to be new facilities.)

- RMW management units in States or Territories not authorized to administer the base RCRA program as of September 23, 1988

Owners/operators of land disposal units in these States or Territories had to submit (1) their Part A permit applications, or modify their existing Part A applications to include mixed waste management units, by March 23, 1989, and (2) their Part $B$ permit applications and certifications of compliance with applicable groundwater monitoring requirements by September 23, 1989, to prevent LOIS. Owners/operators of facilities other than land disposal units must submit Part B of their permit applications in accordance with deadlines established by EPA Regional Offices to prevent LOIS.

- $R M W$ management units in States or Territories authorized to administer the base RCRA program but not authorized for $R M W$

Under the Federal RCRA program, owners/operators of RMW management units in these States or Territories currently have no permit application deadlines associated with LOIS. Other
State laws, however, could have an affect on the ability of RMW management units in these States to operate.

0 RMW management units in States or Territories authorized to administer a $R M W$ program

Owners/operators of land disposal units in these States or Territories must submit Part B permit applications within one year of the effective date of the State's RMW authorization or lose interim status. Owners/operators of facilities other than land disposal units must submit Part B permit applications in accordance with deadlines established in authorized State programs to prevent LOIS.

\section{Can a TSDF lose interim status for reasons unrelated to a failure to meet applicable permit application deadlines?}

Yes. Certain physical changes at an interim status TSDF can result in LOIS [40 CFR 270.72]. In general, changes can be made to an interim status TSDF, as long as approval is obtained from the appropriate regulatory agencies, and the relevant portions of the Part A and Part B permit application are revised to reflect and justify the changes. However, at no time during interim status can changes be made to a TSDF that amount to reconstruction of the facility, unless such changes are necessitated by changes in existing regulations. Reconstruction is considered to have occurred when the capital investment in the changes to the facility excoeds 50 percent of the capital cost of constructing a comparable new facility. If the investment does exceed 50 percent, the facility is considered to be new.

In addition, failure of an interim status facility to comply with applicable regulations can result in the issuance of a compliance order under section 3008(a) of RCRA. Failure to obey a compliance order can result in LOIS.

\section{What regulatory requirements are applicable to} facilities that lose interim status?

TSDFs that lose interim status must perform closure in accordance with 40 CFR 265. Owners/operators of surface impoundments, landfills, land trea tment units, or waste piles must also apply for a post-closure permit unless closure is demonstrated by removal of the waste (clean closure). Refer to EH Information Brief EH-231-009/1291 (December 1991) for information on RCRA Closure and Post-Closure Plans.

\section{What if an interim status facility misses a RCRA permit application deadline?}

Failure to file RCRA permit applications within EPA- or State-mandated schedules can lead to LOIS. It is illegal to operate a hazardous or mixed waste TSDF if the facility does not have interim status or a RCRA permit. Ilegal operation of a hazardous or mixed waste TSDF can lead to shutdown of the operation, fines, criminal penalties, and imprisonment.

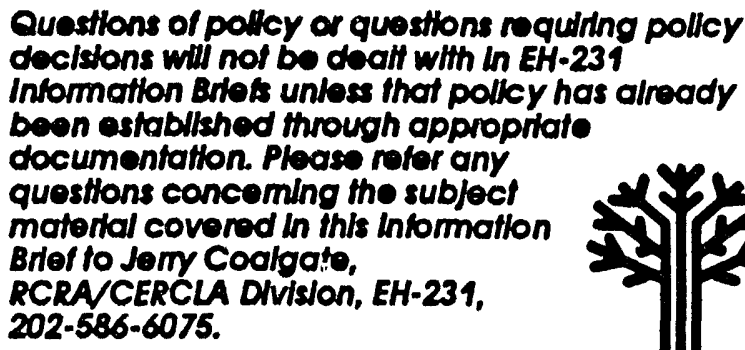



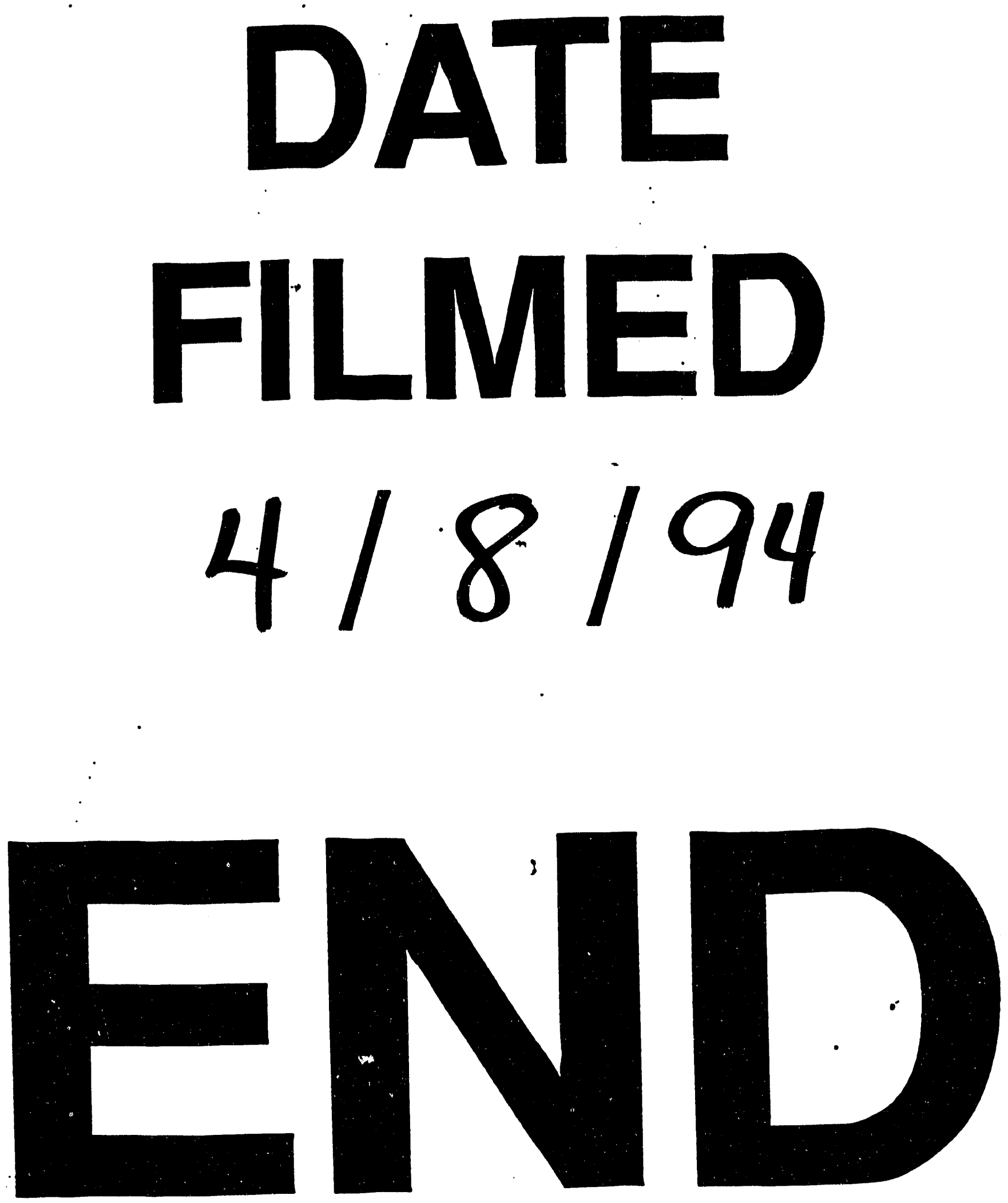
